\title{
Simultaneous determination of hexabromocyclododecanes and tris (2,3-dibromopropyl) isocyanurate using LC-APCI-MS/MS
}

\author{
Jiayong Feng, Yawei Wang*, Ting Ruan, Guangbo Qu, Guibin Jiang \\ State Key Laboratory of Environmental Chemistry and Ecotoxicology, Research Center for Eco-Environmental Sciences, Chinese Academy of Sciences, \\ Shuangqing Road, Haidian District, Beijing 100085, China
}

\section{A R T I C L E I N F O}

\section{Article history:}

Received 27 April 2010

Received in revised form 4 August 2010

Accepted 12 August 2010

Available online 19 August 2010

\section{Keywords:}

Brominated flame retardants

Hexabromocyclododecanes

Tris (2,3-dibromopropyl) isocyanurate

LC-MS/MS

$\mathrm{APCI}$

\begin{abstract}
A B S T R A C T
Hexabromocyclododecanes (HBCDs) and tris (2,3-dibromopropyl) isocyanurate (TBC) are both brominated flame retardants, and have been used throughout the world with subsequent concern for potential environment pollution. Here we describe the development of a method for the simultaneous determination of TBC and HBCD diastereoisomers in environmental matrices by high performance liquid chromatography tandem mass spectrometry (HPLC-MS/MS). The method recovery ranged from $81 \%$ to $93 \%$ and limits of detections (LODs) on column were $4.3 \mathrm{pg}, 0.5 \mathrm{pg}, 0.4 \mathrm{pg}, 0.3 \mathrm{pg}$ for TBC, $\alpha-\mathrm{HBCD}, \beta-\mathrm{HBCD}$, and $\gamma$-HBCD, respectively, which showed high sensitivity compared to previous published methods. Compared to electrospray ionization (ESI), atmospheric pressure chemical ionization (APCI) was found to be a more sensitive, effective ionization mode for determination of HBCDs. This novel method was further validated by analyzing TBC and HBCDs in biotic and abiotic samples. The concentration ranges of TBC, $\alpha, \beta, \gamma$-HBCD in sediment samples were $136.1-5884.6 \mathrm{ng} / \mathrm{g}, 9.0-1079.6 \mathrm{ng} / \mathrm{g}, 1.0-1161.7 \mathrm{ng} / \mathrm{g}$, and $65.4-3964.2 \mathrm{ng} / \mathrm{g}$, respectively. The concentration range for TBC, $\alpha-\mathrm{HBCD}, \beta-\mathrm{HBCD}$, and $\gamma-\mathrm{HBCD}$ in common carp samples were $51.1-1899 \mathrm{ng} / \mathrm{g}, 21.6-1338 \mathrm{ng} / \mathrm{g}$, <LOD-10.9 ng/g, and $1.4-101 \mathrm{ng} / \mathrm{g}$, respectively.
\end{abstract}

\section{Introduction}

Brominated flame retardants (BFRs) have been widely used in plastics, textiles, synthetic fibers and other materials, for the purpose of providing flame retardancy $[1,2]$. The most frequently used BFRs in the past years are tetrabromobisphenol-A (TBBPA) and polybrominated diphenylethers (PBDEs) [2,3]. In the advent of increasing concerns regarding the potential environmental problems that might because by their large production amounts, the penta- and octa-BDE mixtures has recently been listed into the Stockholm Convention on Persistent Organic Pollutants [4,5]. Consequently, the demand for alternative BFRs, such as hexabromocyclododecanes (HBCDs) and tris (2,3-dibromopropyl) isocyanurate (TBC) has steadily increased [6-8].

Mainly used as primary additive flame retardants [2,6], HBCDs (Fig. 1) are currently the third most produced BFR in the world $[5,7,8,10]$. In 2001, the global market demand of HBCD reached 16700 tones and then increased to 22000 metric tones in 2005 $[3,9]$. Because technical HBCD is produced by the bromination of cyclododecatri-1, 5, 9-ene, it mainly contains three diastereoisomers, $\alpha-\mathrm{HBCD}, \beta-\mathrm{HBCD}$, and $\gamma$-HBCD [6]. There are large differences

\footnotetext{
* Corresponding author. Tel.: +86 106284 9334; fax: +86 1062849339

E-mail address: ywwang@rcees.ac.cn (Y. Wang).
}

in regards to the bioaccumulation potential among the individual diastereoisomers $[2,10]$. Previous studies found that $\gamma$-HBCD can be transformed to $\alpha-\mathrm{HBCD}$ at temperatures above $160^{\circ} \mathrm{C}$ [11], and thus HBCD diastereoisomers cannot be separated by GC-MS and only total HBCD concentrations can be obtained by this method [12]. Liquid chromatography-mass spectrometry (LC/MS) and tandem mass spectrometry (LC/MS/MS) are found to easily separate HBCD diastereoisomers using reversed-phase columns [13-17]. Budakowski and Tomy applied the first LC-MS/MS method, but did not achieve a baseline separation of the three diastereoisomers [13]. Morris et al. improved a baseline chromatographic separation method and they investigated the distribution and fate of HBCDs in the North Sea Estuaries [14]. Janak et al. used a chiral LC column to separate the HBCD enantiomers and further discussed the enantiomer fractionation in detail [15]. From then on, studies on HBCDs in different environmental matrices by LC-MS/MS have been steadily increasing $[18,19]$.

Tris (2,3-dibromopropyl) isocyanurate (TBC, Fig. 1) is a BFR with high thermal stability, low viscosity, low tendency towards discoloration and low corrosivity, and has recently been found in the environment [7]. It is added to polypropylene, polyethylene, and polystyrene at a weight proportion of 5-10\% [20]. High octanol-water partitioning coefficient ( $\log \mathrm{Kow})$ of 7.37 has been estimated for TBC by EPA EPI QASR interface V3.2, which shows that TBC can be easily accumulated in sediments and has potential to be 


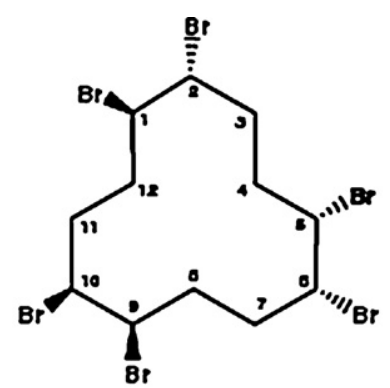

(-) $\alpha-H B C D$ (1 R,2R,5S,6R,9R,10S)

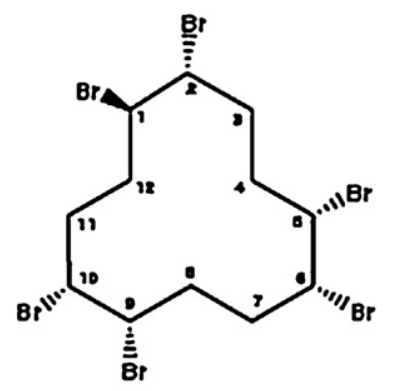

(-) $\beta$-HBCD (1 R,2R,5S,6R,9S, 10R)<smiles>Br[C@H]1CC[C@H](Br)[C@H](Br)CC[C@H](Br)[C@H](Br)CC[C@@H]1Br</smiles>

(-) $\gamma \cdot \mathrm{HBCD}$ $(1 \mathrm{~S}, 2 \mathrm{~S}, 5 \mathrm{~S}, \mathrm{6R}, \mathrm{9R}, 10 \mathrm{~S})$<smiles>O=c1n(CC(Br)CBr)c(=O)n(CC(Br)CBr)c(=O)n1CC(Br)CBr</smiles>

\section{Tris(2,3-dibromopropyl) isocyanurate}

Fig. 1. Structure of HBCD diastereoisomers and TBC.

bioaccumulated in wildlife. Total world production of TBC is not yet known, but judging from the usage and output information in China, its production and potential to be released into the environment should not be ignored $[7,20]$. Very limited studies have been conducted in regards to the distribution of TBC in environment, and the only paper published so far indicated wide distribution of TBC in river water, soil, sediment, and biological samples collected around a manufacturing plant in Hunan province of China [7].

As both TBC and HBCD are produced in large amounts, a sensitive method which can detect both of these BFRs in the environment is warranted. The purpose of this study is to develop a method for the simultaneous determination of the three main HBCD diastereoisomers and TBC using high performance liquid chromatography tandem mass spectrometry (HPLC-MS/MS). Further, sediment and biological samples collected from potential contaminated area were analyzed to validate the suitability of this method for environmental samples.

\section{Materials and methods}

\subsection{Chemicals and stock solutions}

Technical grade TBC (97\%) was purchased from Sigma-Aldrich (St. Louis, MO). Native HBCD standards were obtained from Cambridge Isotope Labs (Andover, MA, USA). Stock solutions $(50 \mu \mathrm{g} / \mathrm{ml})$ of isotopically labeled $\left[{ }^{13} \mathrm{C}_{12}\right] \gamma$-HBCD and $\left[{ }^{2} \mathrm{H}_{18}\right] \gamma$-HBCD were purchased from Wellington Labs (Guelph, Canada) as internal standards. HPLC grade methanol and pesticide residue grade hexane and dichloromethane (DCM) were obtained from Fisher Scientific (Hampton, NH). Deionized water (18.3 M $\Omega$ ) was obtained from an ultrapure water purification system (Barnstead International, Dubuque, IA). Silica gel was obtained from Merck (Whitehouse
Station, NJ). Before use the silica gel was prebaked at $550^{\circ} \mathrm{C}$ for $12 \mathrm{~h}$.

Seven concentration levels $(2 \mathrm{ng} / \mathrm{ml}, 5 \mathrm{ng} / \mathrm{ml}, 10 \mathrm{ng} / \mathrm{ml}$, $20 \mathrm{ng} / \mathrm{ml}, 50 \mathrm{ng} / \mathrm{ml}, 100 \mathrm{ng} / \mathrm{ml}$, and $200 \mathrm{ng} / \mathrm{ml}$ ) of mixed standard solutions of TBC and HBCD were prepared for standard curves.

\subsection{Sampling}

All samples (four biota and three sediment samples) were collected at the Liuyang River, which is located southwest of Liuyang, Hunan province, in southern China. The sampling procedure has been described in detail in our previous work [7]. Sampling sites were located downstream of the outlet of a BFR manufacturing plant. Along the riverside at specific intervals, three surface sediment samples were collected with a grab sampler (Wildco Ekman Grab, $152 \mathrm{~mm} \times 152 \mathrm{~mm} \times 152 \mathrm{~mm}$, Buffalo, NY). After water in the sampler was carefully removed, sediment samples were packed in aluminum foil and sealed in plastic bags. Four common carp samples were collected about $6 \mathrm{~km}$ away from the effluent of the manufacturing plant and then stored in an ice box before being transported to the laboratory and stored in $-20^{\circ} \mathrm{C}$.

\subsection{Sample preparation and cleanup}

All samples were freeze-dried, (soil samples were sieved with a 100 mesh size sieve), and then homogenized. A known amount of the sample ( $1.0 \mathrm{~g}$ for sediment, 0.5 for biota samples) mixed with $\sim 15 \mathrm{~g}$ of anhydrous $\mathrm{Na}_{2} \mathrm{SO}_{4}$ was loaded into an accelerated solvent extraction (ASE) cell (ASE 300, Dionex, Oakville, Canada) under a condition of $150^{\circ} \mathrm{C}$ and 1500 psi with dichloromethane (DCM) as extraction solvent. After extraction, $10 \mathrm{ng}$ of ${ }^{13} \mathrm{C}$-labeled 


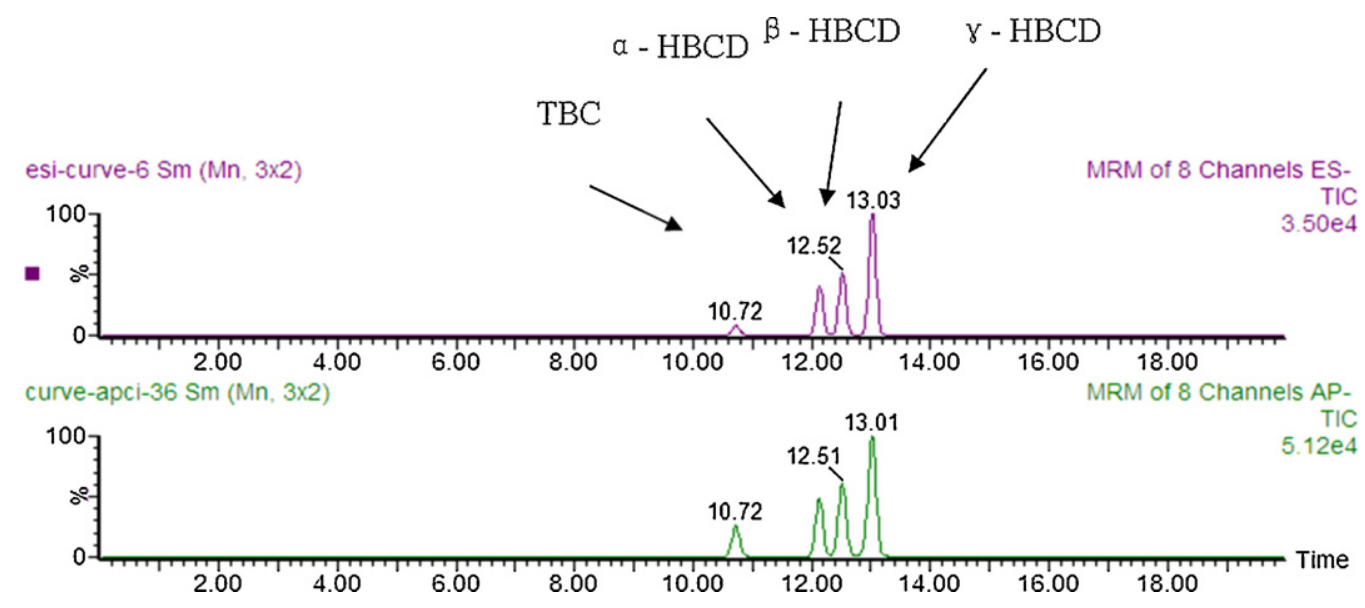

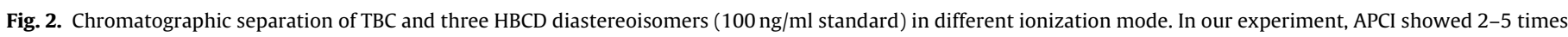
higher sensitivity for HBCD than ESI.

$\gamma$-HBCD was added as internal standard into the extractant. In our preliminary experiment, the matrices had not significantly effect in influencing the LC-MS/MS analyses and there were barely any enhancement or suppression of TBC or the three HBCD diastereoisomers during the ASE procedure. Similar results for HBCD diastereoisomers were also discussed by Dodder et al. and $\mathrm{Yu}$ et al. $[16,17]$. In their work, they all mentioned that matrix interferences in soil and air samples did not significantly influence the accuracy and precision of the diastereomer analysis. $10 \mathrm{~g}$ acidic silica was added to remove impurities, and then, the acidic silica was eliminated though an anhydrous $\mathrm{Na}_{2} \mathrm{SO}_{4}$ column. The extract was collected and concentrated by a rotary evaporator until its volume was $<0.5 \mathrm{ml}$. The concentrated TBC and HBCDs mixtures were loaded onto an activated silica gel column ( $8 \mathrm{~g}$ ). After loading, the extract was eluted with $38 \mathrm{ml}$ hexane followed by $60 \mathrm{ml}$ dichloromethane. The final elutuate was concentrated to $1 \mathrm{ml}$ in 8:2 methanol/water and $10 \mathrm{ng}\left[{ }^{2} \mathrm{H}_{18}\right]-\gamma-\mathrm{HBCD}$ was added as injection internal standard for LC-MS/MS analysis.

\subsection{HPLC conditions}

Instrument analysis was performed on an Alliance 2695 model HPLC system (Waters, Milford, MA) using a ZORBAX C18 reversed-phase chromatographic column $(3 \mathrm{~mm} \times 150 \mathrm{~mm}, 5 \mu \mathrm{m}$, Agilent, USA). The gradient mobile phase consisted of methanol (A)/acetonitrile (B)/water (C). The flow rate was set at $0.4 \mathrm{ml} / \mathrm{min}$. The gradient program started at an initial composition of 30:30:40 $\mathrm{A} / \mathrm{B} / \mathrm{C}(\mathrm{v} / \mathrm{v})$ and was ramped to $70: 30: 0 \mathrm{~A} / \mathrm{B} / \mathrm{C}$ in $10 \mathrm{~min}$, held for $4.9 \mathrm{~min}$ and then returned to $30: 30: 40 \mathrm{~A} / \mathrm{B} / \mathrm{C}$ in $0.1 \mathrm{~min}$. The column was then allowed to be equilibrated for $5 \mathrm{~min}$. The detailed program is listed in Table 1.

\subsection{Mass spectrometry}

The quadrupole MS used in this study was a triple-quadrupole mass spectrometer (Quattro Premier XE, Micromass, Manchester,

\section{Table 1}

Gradient mobile phase program for the separation of TBC, $\alpha-\mathrm{HBCD}, \beta-\mathrm{HBCD}$, and $\gamma$-HBCD.

\begin{tabular}{lllc}
\hline Time $(\mathrm{min})$ & Methanol & Acetonitrile & Water \\
\hline 0 & 30 & 30 & 40 \\
10 & 70 & 30 & 0 \\
14.9 & 70 & 30 & 0 \\
15 & 30 & 30 & 40 \\
20 & 30 & 30 & 40 \\
\hline
\end{tabular}

UK). The Q1 scan ranges were $m / z \quad 600-690$ and $m / z$ 690-750, operated with unit resolution for a scan time of $0.2 \mathrm{~s}$. Both in ESI and APCI mode, the multiple reaction monitoring (MRM) signal from $\mathrm{m} / \mathrm{z} 640.6 \rightarrow 79$ transition was used for quantification and $m / z 640.6 \rightarrow 81$ for confirmation of HBCD, and for TBC, $\mathrm{m} / \mathrm{z} 727.8 \rightarrow 79$ transition was used for quantification and $\mathrm{m} / \mathrm{z}$ $727.8 \rightarrow 81$ for confirmation. The compounds were quantified by isotope-dilution method using isotopically labeled $\left[{ }^{13} \mathrm{C}_{12}\right] \gamma$-HBCD $(m / z 652.6 \rightarrow 79,81)$ and $\left[{ }^{2} \mathrm{H}_{18}\right] \gamma-\mathrm{HBCD}(\mathrm{m} / z 658.6 \rightarrow 79,81)$, using a $0.2 \mathrm{~s}$ dwell time per transition. Both electrospray ionization [ESI] and atmospheric pressure chemical ionization [APCI] modes were performed in negative ion modes. For simultaneous determination, the optimized MS/MS parameters were chosen for TBC, a little different from the conditions of HBCD. Details of the optimized MS/MS parameters in ESI and APCI mode are listed in Table 2.

\subsection{Validation study}

Quantification was performed by isotope-dilution method. $\left[{ }^{13} \mathrm{C}_{12}\right] \gamma$-HBCD and $\left[{ }^{2} \mathrm{H}_{18}\right] \gamma$-HBCD were used as recovery and internal standard for indicating the accuracy of the pretreatment and instrument analysis of the method, respectively.

The linearity of APCI mode was studied by analyzing standard solutions in triplicate at seven concentration levels $(2 \mathrm{ng} / \mathrm{ml}$, $5 \mathrm{ng} / \mathrm{ml}, 10 \mathrm{ng} / \mathrm{ml}, 20 \mathrm{ng} / \mathrm{ml}, 50 \mathrm{ng} / \mathrm{ml}, 100 \mathrm{ng} / \mathrm{ml}$, and $200 \mathrm{ng} / \mathrm{ml}$ ). The selectivity was studied by analyzing a blank sample to check for absence of analyte ions which was then compared to the IS. The accuracy and precision was studied by analyzing quality control samples at two concentration levels $(20 \mathrm{ng} / \mathrm{ml}, 100 \mathrm{ng} / \mathrm{ml})$. All experiments were performed in triplicate. The signal-to-noise ratio of the limit of quantification (LOQ) and limit of detection (LOD) was set as 10:1 and 3:1, respectively.

Table 2

Optimized MS/MS parameters for the determination of TBC, $\alpha-, \beta-$, and $\gamma-\mathrm{HBCD}$ in ESI and APCI mode.

\begin{tabular}{lcc}
\hline Parameter & $\begin{array}{l}\text { Optimised value } \\
\text { for ESI }\end{array}$ & $\begin{array}{l}\text { Optimised value } \\
\text { For APCI }\end{array}$ \\
\hline Capillary voltage $(\mathrm{V})$ & 2.7 & - \\
APCI probe temperature $\left({ }^{\circ} \mathrm{C}\right)$ & - & 150 \\
Cone voltage $(\mathrm{V})$ & 28 & 30 \\
Source temperature $\left({ }^{\circ} \mathrm{C}\right)$ & 110 & 120 \\
Desolvation temperature $\left({ }^{\circ} \mathrm{C}\right)$ & 150 & 320 \\
Desolvation gas flow $(\mathrm{l} / \mathrm{h})$ & 450 & 450 \\
Cone gas flow $(\mathrm{l} / \mathrm{h})$ & 50 & 50 \\
Collision energy $(\mathrm{ev})$ & 11 & 11 \\
\hline
\end{tabular}




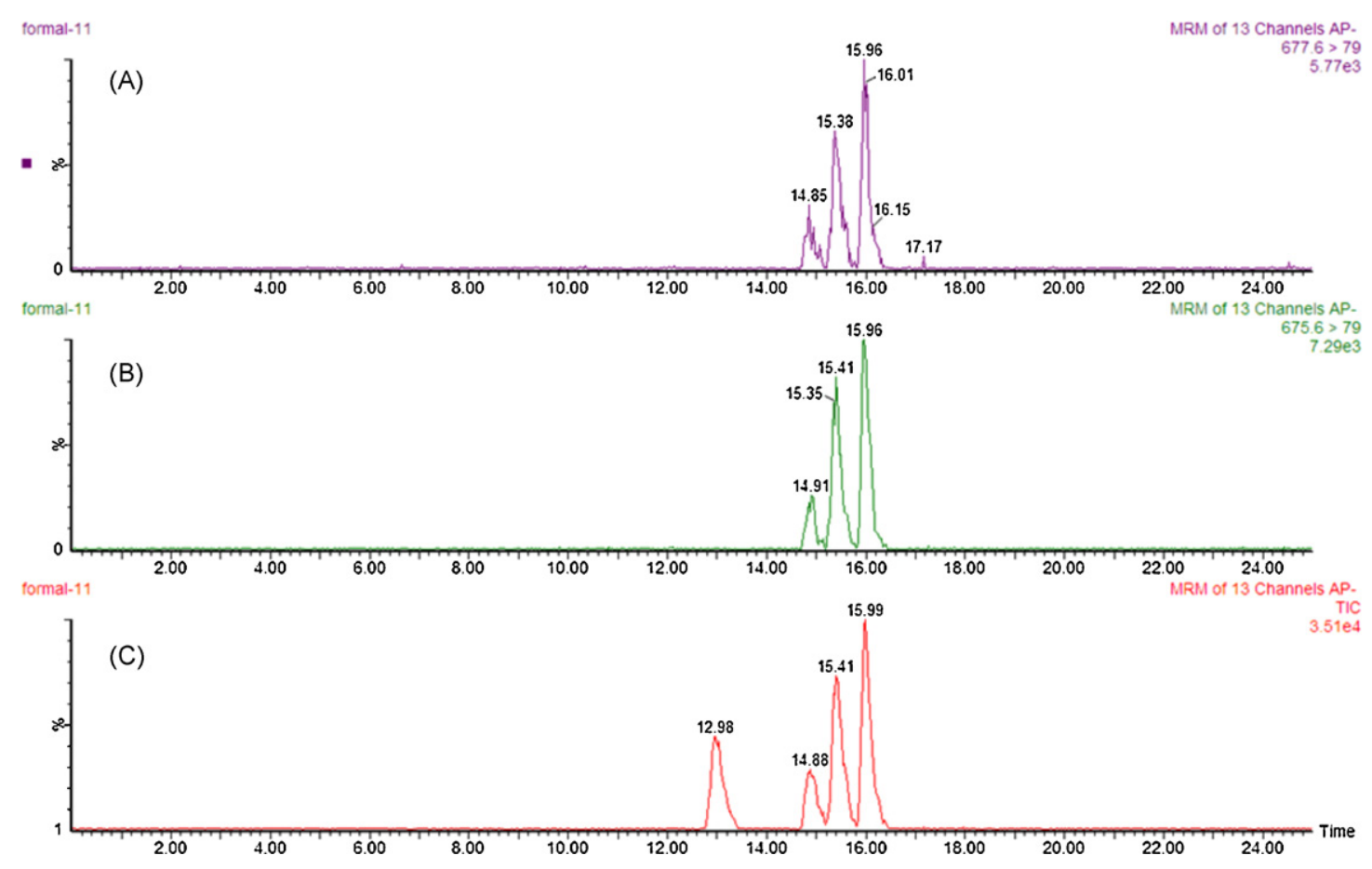

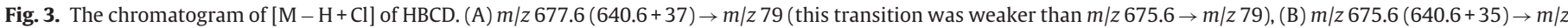
79 , (C) Full chromatogram of TBC and HBCD. From this figure we can see the signal intensity of $[\mathrm{M}-\mathrm{H}+\mathrm{Cl}] \mathrm{was}$ very strong.

\section{Results and discussion}

\subsection{Chromatographic separation}

Chromatographic separations of TBC and three diastereoisomers of HBCD were carried out by reversed-phase chromatography using a C18 column. The investigation on retention behavior of TBC and HBCD in different mobile phases in the APCI and ESI mode revealed that: (1) with the increase of the proportion of methanol to acetonitrile in the mobile phase (from volume ratio of 1:9-9:1), the signal intensity of TBC and $\beta$-HBCD increased, while the signal intensity of $\alpha-\mathrm{HBCD}$ and $\gamma$-HBCD decreased, and the resolution (resolution represents relative distance of two peaks in the chromatogram) became lower between every two peaks of TBC and HBCD diastereoisomers; (2) when the proportion of methanol to water increased, the signal intensity of TBC and the three HBCD diastereoisomers became weaker, but the resolution was higher between every two peaks of TBC and HBCD diastereoisomers; (3) in APCI mode, when using different concentrations of ammonium acetate as the buffer solution $(0 \mathrm{mM}, 5 \mathrm{mM}, 10 \mathrm{mM}, 15 \mathrm{mM})$, higher concentrations resulted in weaker signal intensity of $\mathrm{HBCD}$ diastereoisomers and TBC. The baseline became higher while the resolutions were almost unchanged. However, when using ESI for analysis, with the increase of concentration of ammonium acetate buffer, the signal intensity of three HBCD diastereoisomers and TBC became stronger, which was in accord with the results from Yu et al. [19].

The adverse effects by the ammonium acetate buffer may be explained by the different ionization mechanisms. In the case of ESI, the mobile phase undergoes evaporation and then through a coulomb explosion which results in charged nanodroplets. As the process continues, the ions are isolated in the gas phase either by a combination of evaporation of charged nanodroplets or an electricfield-induced mobility $[21,22]$. The APCI mechanism relies on a corona-needle discharge and the ions are produced by a charge transfer procedure. If competing ions are present and competes with the analyte ion for the charge, the analyte ion signal would be suppressed $[23,24]$. Therefore, in the present experiment, the ammonium acetate buffer was not used neither ESI nor APCI modes. As shown in Fig. 2, the peaks of the three HBCD diastereoisomers and TBC were adequately separated from each other both in ESI and APCI mode.

\subsection{MS/MS optimization}

In order to attain highest sensitivity, optimization of MS condition was performed through injecting $10 \mu \mathrm{l}$ of individual standard solutions into a stream of $\mathrm{MeOH} /$ water $(7 / 3)$ at a flow rate of $0.30 \mathrm{ml} / \mathrm{min}$ by flow injection analysis (FIA). Each parameter adjustment was repeated five times to ensure signal intensity stability.

When using ESI for analysis, the most important factors are desolvation gas flow (optimized scope: 150-600 l/h), source temperature (optimized scope: $50-450^{\circ} \mathrm{C}$ ) and desolvation temperature (optimized scope: $50-450^{\circ} \mathrm{C}$ ). For TBC, optimized value for the three parameters were $4501 / \mathrm{h}, 110^{\circ} \mathrm{C}$ and $150^{\circ} \mathrm{C}$, respectively and for $\mathrm{HBCD}$ were $550 \mathrm{l} / \mathrm{h}, 120^{\circ} \mathrm{C}$ and $320^{\circ} \mathrm{C}$, respectively.

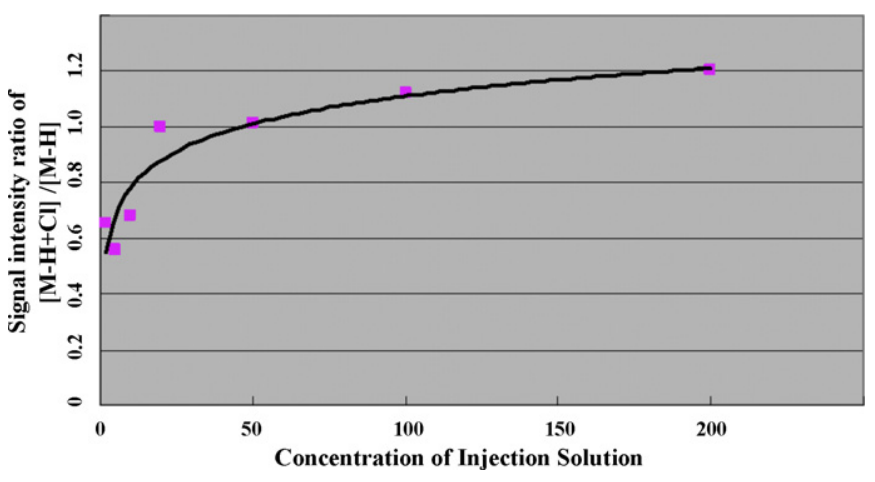

Fig. 4. The ratio of $[\mathrm{M}-\mathrm{H}+\mathrm{Cl}] /[\mathrm{M}-\mathrm{H}]$ was increasing with a higher concentration of injection solution. When the injection volume was $1 \mathrm{ng}(50 \mathrm{ppb} \times 20 \mu \mathrm{l})$, the signal intensity of $[\mathrm{M}-\mathrm{H}+\mathrm{Cl}]$ was stronger than that of $[\mathrm{M}-\mathrm{H}]$, and we found the ratio of $[\mathrm{M}-\mathrm{H}+\mathrm{Cl}] /[\mathrm{M}-\mathrm{H}]$ was increasing with a higher concentration of injection solution. 


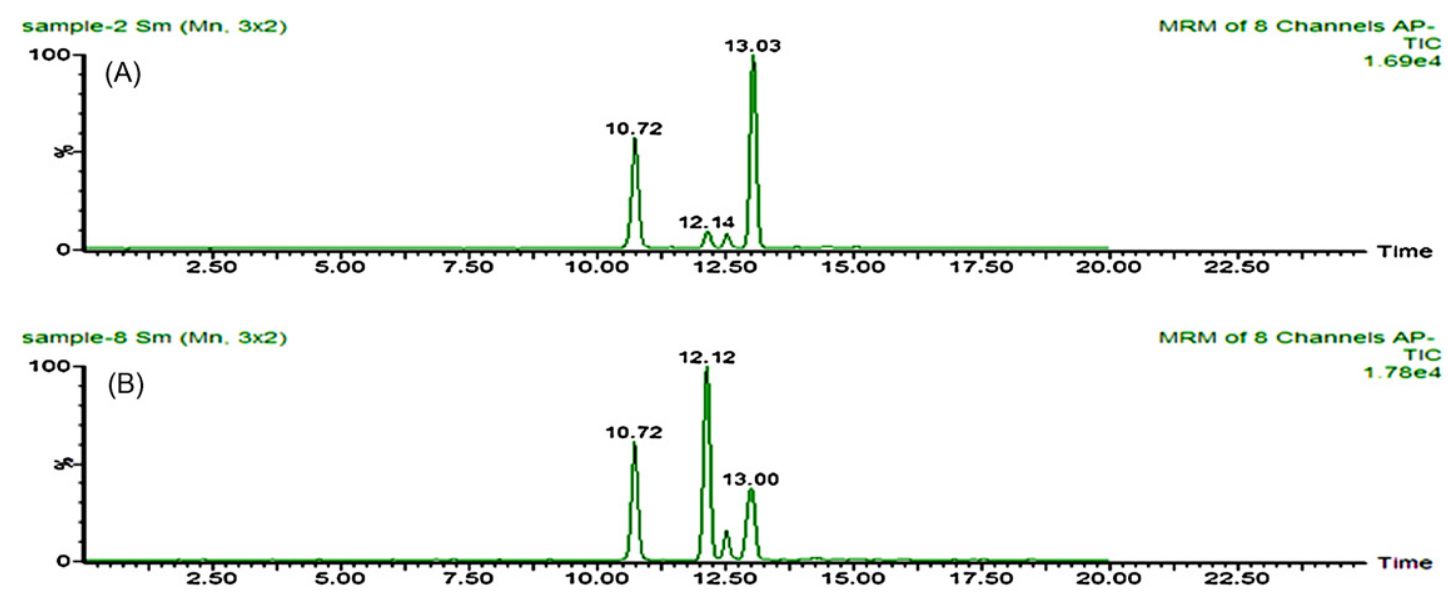

Fig. 5. Chromatograms obtained from real samples analysis. (A) Sediment sample, (B) carp sample.

When APCI was employed, different probe temperatures (optimized scope: $50-450^{\circ} \mathrm{C}$ ) was studied for the simultaneous analysis of $\mathrm{TBC}$ and $\mathrm{HBCD}\left(150^{\circ} \mathrm{C}\right.$ and $250^{\circ} \mathrm{C}$, respectively). The collision energy was also varied (for TBC $11 \mathrm{eV}$ and for HBCD $15 \mathrm{eV}$ ).

Usually, ESI is considered a more sensitive ionization method than APCI, which has been discussed in other studies $[13,16]$. However, in our work, APCI showed 2-3 times higher sensitivity for HBCD than ESI, which was also confirmed by Suzuki et al, who found that APCI were approximately 2-5 times more sensitive than ESI for HBCD [25]. For TBC, both ionization sources provided almost the same sensitivity. For HBCD analysis, no other strong transitions are usually found except $\mathrm{m} / \mathrm{z} 652.6 \rightarrow \mathrm{m} / \mathrm{z} 79$ when using ESI mode. However, additional transitions including $\mathrm{m} / \mathrm{z}$ $675.6(640.6+35) \rightarrow m / z 79, m / z 677.6(640.6+37) \rightarrow m / z 79, m / z$ $710.6(640.6+35+35) \rightarrow m / z 79, m / z 712.6(640.6+35+37) \rightarrow m / z$ $79,714.6(640.6+37+37) \rightarrow m / z 79$ could be observed when APCI mode was selected in this study (Fig. 3 ). These indicated that chlorine $[\mathrm{M}-\mathrm{H}+\mathrm{Cl}]$ and $[\mathrm{M}-\mathrm{H}+2 \mathrm{Cl}]$ adduct ions were also present. This weak signal of $[\mathrm{M}-\mathrm{H}+\mathrm{Cl}]$ adduct ion was also found by Morris et al. [14]. Here in our experiment, when the injection volume was $1 \mathrm{ng}(50 \mathrm{ppb} \times 20 \mu \mathrm{l})$, the signal intensity of $[\mathrm{M}-\mathrm{H}+\mathrm{Cl}]$ was stronger than that of $[\mathrm{M}-\mathrm{H}]$, and we found that the ratio of $[\mathrm{M}-\mathrm{H}+\mathrm{Cl}] /[\mathrm{M}-\mathrm{H}]$ increased with a higher concentration of injection solution (Fig. 4). But for TBC, similar phenomenon could not be found, which may be explained by the different structures between HBCDs and TBC. In ESI mode, the $[\mathrm{M}-\mathrm{H}+\mathrm{Cl}]$ signal could barely be observed, which indicated that APCI was a softer ionization mode and more selective to determine HBCDs.

\subsection{Method performance}

In order to verify the stability of the method, run-to-run and day-to-day $(n=3)$ variability was assessed at both high $(100 \mathrm{ng} / \mathrm{ml})$ and low $(20 \mathrm{ng} / \mathrm{ml})$ concentrations (injection volume $=20 \mu \mathrm{l}$ ). The relative standard deviations of run-to-run and day-to-day were 1.9-3.8\% and 2.9-5.9\%, respectively. Method blanks of TBC and HBCD diastereoisomers were lower than their limits of detection (LOD). Within the range of $2-200 \mathrm{ng} / \mathrm{ml}$ (injection volume $=20 \mu \mathrm{l}$ ), the linearity of the method was satisfactory, with $R^{2}$ values for TBC, $\alpha-\mathrm{HBCD}, \beta-\mathrm{HBCD}, \gamma-\mathrm{HBCD}$ at 0.9995, 0.9991, 0.9998, and 0.9986, respectively. $\operatorname{LOD}$ ( signal/noise $=3$ ) for the method for TBC, $\alpha-\mathrm{HBCD}$, $\beta$-HBCD, and $\gamma$-HBCD were $4.3 \mathrm{pg}, 0.5 \mathrm{pg}, 0.4 \mathrm{pg}, 0.3 \mathrm{pg}$, respectively (using APCI).

Four fish and three sediment samples were chosen to confirm the validity of the method. The results showed that the recoveries ranged from $81 \%$ to $93 \%$. All the instrument analysis was carried out using both APCI and ESI. We found the two results were at the same order of magnitude, and the concentrations were therefore given by the APCI results. Chromatograms obtained from real samples are given in Fig. 5.

Levels of HBCD diastereoisomers found in sediment samples were in the range of $136.1-5884.6 \mathrm{ng} / \mathrm{g}$ for TBC, $9.0-1080 \mathrm{ng} / \mathrm{g}$ for $\alpha-\mathrm{HBCD}, 1.0-1161 \mathrm{ng} / \mathrm{g}$ for $\beta-\mathrm{HBCD}$, and $65.4-3964 \mathrm{ng} / \mathrm{g}$ for $\gamma$-HBCD, which indicated that $\gamma$-HBCD was the dominating isomers in sediment samples. The concentration levels decreased with increasing distance between the sampling location and the sewage outfall. The results of TBC corresponded quite well with those from our previous work [7]. The concentrations of HBCD diastereoisomers were higher than those found in Detroit River suspended sediments [26] ( $\alpha$-HBCD: $0.025-1.9 \mathrm{ng} / \mathrm{g}, \quad \beta-\mathrm{HBCD}$ : $0.025-0.28 \mathrm{ng} / \mathrm{g}, \gamma-\mathrm{HBCD}: 0.025-2.3 \mathrm{ng} / \mathrm{g}$ ).

The range of concentration of TBC, $\alpha-\mathrm{HBCD}, \beta-\mathrm{HBCD}$, and $\gamma$-HBCD in four common carp samples were in the range of $51.1-1899 \mathrm{ng} / \mathrm{g}, 21.6-1338 \mathrm{ng} / \mathrm{g}$, <LOD-10.9 $\mathrm{ng} / \mathrm{g}$, and $1.4-101 \mathrm{ng} / \mathrm{g}$, respectively, which indicated that $\gamma$-HBCD was the predominant isomer in the fish samples. Compared to previous studies [27], concentrations of HBCD diastereoisomers were at the high levels.

Comparing with previous studies on HBCD diastereoisomers, such as Yu et al. [17] (which needed $43 \mathrm{~min}$ to separate the three HBCD diastereoisomers and with LODs on column of $0.5 \mathrm{pg}, 0.3 \mathrm{pg}$ and $0.3 \mathrm{pg}$ for $\alpha-\mathrm{HBCD}, \beta-\mathrm{HBCD}$, and $\gamma-\mathrm{HBCD}$ ), Morris et al. [14] (time of separation was $40 \mathrm{~min}$ and LOQs on column were $150 \mathrm{pg}$ ), the resolution, analytical time and LODs of the our method were almost the same as the best results from those studies. Most importantly, the emerging brominated flame retardant, TBC, could also be simultaneously determined using the same conditions of pretreatment and instrument analysis.

\section{Conclusion}

A highly sensitive method for the simultaneous determination of TBC and HBCD was developed based on LC-MS/MS. With a methanol/acetonitrile/water LC gradient, baseline chromatographic separation could be achieved for TBC and HBCD in $15 \mathrm{~min}$. Compared to separate analysis of HBCD and TBC, simultaneous determination reduced the process time for sample preparation and LC-MS/MS analysis, without noticeable effect on the sensitivity. APCI was found to be more sensitive to determine HBCDs than ESI, which was different from the results of some previous published studies. Determining of fish and sediment indicated that the method was effective and feasible with sample recoveries ranging from $81 \%$ to $93 \%$. 


\section{Acknowledgement}

This work is jointly supported by National Natural Science Foundation of China (20677068), National Basic Research Program of China (2009CB421605) and the High tech Research and Development Programme (2007AA061602).

\section{References}

[1] C. de Wit, Chemosphere 46 (2002) 583.

[2] M. Alaee, P. Arias, A. Sjödin, Å. Bergman, Environ. Int. 29 (2003) 683.

[3] Bromine Science and Environmental Forum (BSEF), http://www.bsef.com (accessed September 2004).

[4] L.S. Birnbaum, D.F. Staskal, Environ. Health Perspect. 112 (2004) 9.

[5] A. Covaci, A.C. Gerecke, R.J. Law, S. Voorspoels, M. Kohler, N.V. Heeb, H. Leslie, C.R. Allchin, J. de Boer, Environ. Sci. Technol. 40 (2006) 3679.

[6] N.V. Heeb, W.B. Schweizer, M. Kohler, A.C. Gerecke, Chemosphere 61 (2005) 65.

[7] T. Ruan, Y.W. Wang, C. Wang, P. Wang, J.J. Fu, Y.G. Yin, G.B. Qu, T. Wang, G.B. Jiang, Environ. Sci. Technol. 43 (2009) 3080.

[8] J.C.W. Lam, R.K.F. Lau, M.B. Murphy, P.K.S. Lam, Environ. Sci. Technol. 43 (2009) 6944.

[9] T. Isobe, K. Ramu, N. Kajiwara, S. Takahashi, P.K.S. Lam, T.A. Jefferson, K. Zhou, S. Tanabe, Mar. Pollut. Bull. 54 (2007) 1139.
[10] R.J. Law, M. Alaee, C.R. Allchin, J.P. Boon, M. Lebeuf, P. Lepom, G.A. Stern, Environ. Int. 29 (2003) 757.

[11] F. Barotini, V. Cozzani, L. Petarca, Ind. Eng. Chem. Res. 40 (2001) 3270.

[12] A. Covaci, S. Voorspoels, J. de Boer, Environ. Int. 29 (2003) 735.

[13] W. Budakowski, G. Tomy, Rapid Commun. Mass Spectrom. 17 (2003) 1399.

[14] S. Morris, P. Bersuder, C.R. Allchin, B. Zegers, Trends Anal. Chem. 25 (2006) 4.

[15] K. Janak, A. Covaci, S. Voorspoels, G. Becher, Environ. Sci. Technol. 39 (2005) 1987.

[16] N.G. Dodder, A.M. Peck, J.R. Kucklick, L.C. Sander, J. Chromatogr. A 1135 (2006) 36.

[17] Z.Q. Yu, P.A. Peng, G.Y. Sheng, J.M. Fu, J. Chromatogr. A 1190 (2008) 74.

[18] A.M. Peck, R.S. Pugh, A. Moors, M.B. Ellisor, B.J. Porter, P.R. Becker, J.R. Kucklick, Environ. Sci. Technol. 42 (2008) 2650.

[19] Z.Q. Yu, L.G. Chen, B.X. Mai, M.C. Wu, G.Y. Sheng, J.M. Fu, P.A. Peng, Environ. Sci. Technol. 42 (2008) 3996.

[20] X. Xiong, Mater. Technol. 3 (1999) 1.

[21] M. Dole, L.L. Mack, R.L. Hines, R.C. Mobley, L.D. Ferguson, M.B. Alice, J. Chem. Phys. 49 (1968) 2240.

[22] P. Kebarle, J. Am. Soc. Mass Spectrom. 35 (2000) 804.

[23] D.W. Griffiths, H. Bain, N. Deighton, N.P. Botting, A.A.B. Robertson, Phytochem Anal. 11 (2000) 216.

[24] R.E. Ardrey, Liquid Chromatography-Mass Spectrometry: An Introduction, John Wiley and Sons Ltd., Chichester, 2003.

[25] S. Suzuki, A. Hasegawa, Anal. Sci. 22 (2006) 469.

[26] C.H. Marvin, G.T. Tomy, M. Alaee, G. MacInnis, Chemosphere 64 (2006) 268

[27] Q. Xian, K. Ramu, T. Isobe, A. Sudaryanto, X. Liu, Z. Gao, S. Takahasho, H. Yu, S Tanabe, Chemosphere 71 (2008) 268. 